\title{
Measuring Performance of Non Government Organizations: A Comparative Study of AMDA Nepal and General Welfare Pratisthan (GWP)
}

\author{
SangitaThapa, M. Phil. \\ Lecturer \\ Department of Management \\ Janamaitri Multiple Campus, Kuleshwar, Kathmandu \\ Email: thapasangita484@gmail.com
}

\begin{abstract}
The number of NGOs has grown significantly over the past several years which shows significant development. The NGOs have been contributing in the different sectors of life like health, education, environment, agriculture, inclusion, social justice, democracy, good governance and many more in collaboration with different partners in local, national and global level. So their work is diverse and complex in nature. NGOs are formed for social reform and citizen's awareness. NGOs wish to address their stakeholder's desire through the operational performances. NGOs can't afford to limit their role into a single sector because they work with the people and for the people. The performance of NGOs play vital role in discharging the accountability placed on them and to meet the expectation of the stakeholders. Therefore, performance of NGOs is key satisfier to the interest of the different stake holders and society at large. There are many factors that contribute in the organizational performance. To measure the organizational performance, independent variables like quality orientation, work climate, employee satisfaction, growth and relationship, organizational strategies and organizational diagnosis are useful. Some demographic variables such as age, gender, education and work experience are also considered as moderating variables. This has provided the status of performance and correlation
\end{abstract}


between the variables. Therefore, it is beneficial to understand these internal variables so that management can take appropriate action to improve the performance.

Key words: Non-government, organizational performance, factors affecting performance.

\section{Conceptual Background}

Role of the NGOs has been increasing in the present world and NGOs have remained as a partner in development efforts of the country from the past. The NGOs and their contributions in the different sector of life like health, education, environment, agriculture, inclusion, social justice, democracy, good governance and many more in collaboration with different partners in local, national and global level is obvious. So their working is diverse and complex in nature.

The history of NGOs in Nepal is not very long. Before 1990, the Panchayat regime exercised tight control over NGOs. There were only 10 NGOs in 1960. It increased to 37 in 1977. But the situation changed dramatically after 1990. After that their number has increased to 10,555 in the year 2000. There are 30,284 NGOs registered with Social Welfare Council till June 2014. A non-governmental organization (NGO) is a social organization motivated to work in sectors like religion, sociocultural, economic, educational, environment, women, children, etc, irrespective of any political ideology and belief. NGOs are formally registered at the Chief District Officer's office and affiliated with the Social Welfare Council (SWC) and renewed annually.

\section{Significance of the study}

As this study is related to measuring, the factors that affect the performance of NGOs selected for this case study. This study would be helpful in knowing what factors affect the performance most and what are the major contributors for the operational success of NGOs. The performance measurement gives the feedback mechanism for the overall operation of the organization. This study will explore the relationship between the factors itself and its effect on the performance of the NGOs. In short, this research helps to know the various variables, which directly or indirectly influence the performance of the organization.

\section{Statement of the problem}

In general, the objectives of NGOs are social reform and citizen's awareness building. Now a days most of the NGOs wish to address their stakeholder's desire through the operational performances. NGOs can't limit to afford their role into a single sector because they work with the people and for the people. Thus, the measurement of the organizational performance becomes must. 
The number of NGOs has grown significantly over the past several years which show that NGOs have growing roles in development partnership. The performance of NGOs plays vital role in discharging the accountability placed on NGOs and to meet the expectation of the stakeholders or organizational management. Therefore, performance of NGOs is key satisfier to the interest of the different stake holders and society at large. The factors that contribute in the organizational performance need to be searched out for improving organizational performance. There are few research studies done to find out what actually affects the performance of NGO's in Nepal.

\section{Research questions}

The following research questions are set for this research:

- What are the factors that contribute to the performance of an NGO?

- Does management play role to the operational performance?

- Whether the employee's role is crucial in the operational performance?

- Does the working condition differentiate the level of performance in NGOs?

\section{Objectives of the study}

This research is focused on the performance of the NGOs. Accordingly, the objectives of the study are as follows:

- To examine the operational performance of NGOs in Nepal

- To analyse the factors that contributes to the status of performance of NGOs in comparative perspective.

- To assess the measurement criteria of performance.

\section{Research hypothesis}

The research hypothesis for this study can be outlined as:

H1: There is significant relationship between the operational performance and work climate.

$\mathrm{H} 2$ : There is a significant internal relationship between the operational performance and the personal growth.

H3: Employees satisfaction has the significance relationship with the operational performance of an organization.

\section{Literature Review}

The NGOs have been existed in Nepal in the various forms of Guthi (Trust), Dhikur (saving \& credit) and Parma (labour exchange) etc, like the unification of Nepal in until 1769. They were established for the common purpose and on the religious ground to serve the certain group. The formal form of NGO came into existence in 1926 after the establishment of Shree Chandra Kamadhenu Charkha Mahaguthi as a social organization for the delivery of services other than the government, which was subsequently followed by Paropakar Sanstha (Dhakal, 2006). 
According to Dhakal (2007) Establishment of modern NGOs in Nepal before 1950 was not easy for the common people as one had to get permission from the Prime Minister. The aftermath of the democratic movement in 1951 created a favorable environment for creating such entities. However, the introduction of Panchayat policy (a party-less political system) in 1961 again created obstacles for the smooth growth of such organizations. It was simply because of suspicion on the role of social organizations contributing people's awareness level thereby creating a probable threat for the continuation of the autocratic nature of the then political system. As a result the growth of NGOs during 1961-90 was very slow".

\section{Meaning and definition of NGOs}

NGO word itself covers all the organizations except the government owned and a conventional profit oriented organization. The term NGO originated with the establishment of the United Nations in 1945 to reflect that they are not a part of a government. The Norwegian bilateral aid agency Norwegian Agency for Development Cooperation (NORAD) (2004) defines development-oriented NGOs as organizations that attempt to improve social, economic and productive conditions and are found both as small community-based organizations at village and district levels and as large professional development agencies at state or national level.

According to Ali Mostashari \& Iranian (2005) NGOs can be distinguished into two groups: Operational and advocacy NGOs. This may be interpreted as the choice between small-scale change achieved directly through projects and large-scale change promoted indirectly through influence on the political system.

Social Welfare Council has classified 30,284 NGOs registered with them into following categories based on their activities or the project they have been implementing.

Table 2.1: Social Welfare Council

\begin{tabular}{|c|c|}
\hline Sector & Number of NGOs registered with Social Welfare Council \\
\hline 1. Child Welfare & 951 \\
\hline 2. Educational Development & 492 \\
\hline 3. Environmental Protection & 1,318 \\
\hline 4. Health Service & 703 \\
\hline 5. Women Service & 2,305 \\
\hline 6. Youth Service & 4,321 \\
\hline 7. Moral Development & 876 \\
\hline 8. Handicapped \& Disabled & 597 \\
\hline 9. AIDS Abuse Control & 88 \\
\hline 10. Community and Rural Development & 18,633 \\
\hline Total & 30,284 \\
\hline
\end{tabular}

Source: Social Welfare Council, 2014 


\section{Concept of performance}

The organizational performance is the dependent variable for this study. To measure the operational performance of an organization, six independent variables have been used. Organizational performance is a complex and multi-dimensional phenomenon. Campbell et al. (1977) imagined, the effectiveness criteria must be chosen with reference to the purpose of measurement. Galbraith (1977) stated, the effectiveness in accomplishing objectives could be affected by three kinds of bottlenecks with respect to theoretical, resource and organizational.

\section{Measuring performance of NGOs}

Due to the growing number and trust of multiple stakeholders' expectation on NGOs, it is obvious that performance should be monitored and measured on some concrete basis. For doing so, different efforts have been made to satisfy the demands of different stakeholder and society at large. Different measurement techniques have been introduced and tested to assess the performance of NGOs.

\section{Concept of organizational performance}

Organizations are established with certain objectives. Organizations require the resources to achieve their objectives. The main resources are man, machines, materials and money. Every organization has its own system, procedure and policies to carry out the activities. Policies are the guidelines that help the organization to run smoothly and effectively. Among the resources employed, it is the human capital, which is the central focus for achieving objectives. Human capital is an asset for any organization. The performance of the organization is dependent on utilization of the resources placed on them. Organizational performance is affected by internal and external environment which is no exception to NGOs.

Organization does not have control over the external environment. However, organizations can exercise control over the internal environment. Internal environment includes staffing and their relationship, management and its attitude, organizational culture, financial and non-financial resources. Among the internal environmental variables affecting the organizational performance are employee satisfaction, growth and relationship, work climate, organizational strategies, diagnosis and how the quality of the work is defined

in the organization and how people are held accountable for performance, work climate and organizational culture. There are other variables such as external, legal-political environment that affects the performance of the organization, which are not considered here in this study.

Organizational performance is the collective outcome of the organization in achieving the objective. Organizational performance can be measured from different perspectives. They can be measured either in term of financial, non-financial or operational aspects. Financial performance is related with measuring how the organization have generated 
and utilized the financial resources in terms of achieving the objectives. Such type of financial performance measures the financial soundness of the organizations. Nonfinancial performance or programmatic performance is related with achieving the set target of the programs or it is related with measuring the status of the desired outcomes of the program implementation.

\section{Theoretical framework}

Theorists like P. R. Lawrence, J. W. Lorsch found that organizations operating in low stable environment operated more effectively if organization structure was less formulated more decentralized and more reliant on mutual adjustment between various departments in an organization. On the other hand, organization operating in more stable and certain environment functioned more effectively if the organization was formalized, centralized in decision making and less mutual adjustments between departments.

\section{Regression model for the organization performance}

$\begin{array}{ll}\text { Organization Performance }=\mathrm{QO}+\mathrm{WC}+\mathrm{ES}+\mathrm{OS}+\mathrm{OD}+\mathrm{R}+\mathrm{PG} \\ \mathrm{OP}=\text { Organization Performance } & \mathrm{QO}=\text { Quality Oriented } \\ \mathrm{WC}=\text { Work Climate } & \mathrm{ES}=\text { Employee's Satisfaction } \\ \mathrm{OS}=\text { Organizational Strategies } & \mathrm{OD}=\text { Organizational Diagnosis } \\ \mathrm{OR}=\text { Relationships } & \mathrm{PG}=\text { Personal Growth }\end{array}$

Through this regression model the independent variables will be used to analyze their affect on the organizational performance. Based on the various studies of research work and the variables used both the independent and depended variables the following framework has been constructed.

\begin{tabular}{|ll|}
\hline Independent Variables \\
- & Quality Oriented \\
- & Eork Climate \\
- & Organizationee's Satisfaction \\
& Strategies \\
- & Organizational \\
& Diagnosis \\
- Relationship \\
- Personal Growth \\
\hline
\end{tabular}

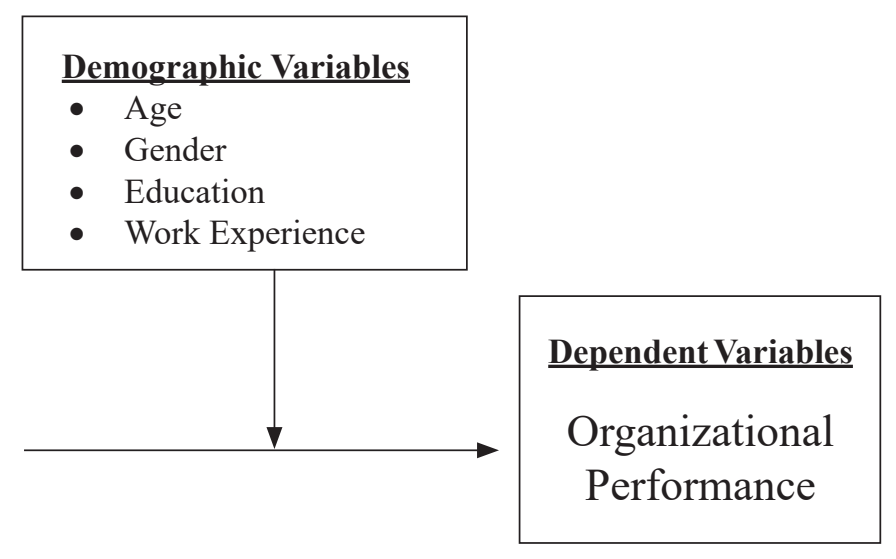

Figure 2.2: Theoretical Framework

\section{Bases of measuring performance of non-government organizations}

Age, gender, education and work experience are the moderating variables. They also affect directly or indirectly on the performance of the organization performance. There 
are numerous variables that are studied for measuring the performance of an organization. The variables which are derived from the different theories are quality, strategy, structure, staff, skills, system and shared values. Beside these there are other variables which are extensively used by the researcher for measuring the performance of an organization. They includes :

Performance planning

Setting strategy

Planning activities

Measuring performance

Feedback and scope indicators

Managing relationship

Technical quality

Communicating performance

Transparency

\section{Research Methodology}

\section{Research design}

As the study is carried out to assess comparative performance management of NGOs, both qualitative and quantitative approach of research has been used. Research design provides a framework for the research study. Descriptive and explanatory research design have been used in this study. The justification for applying qualitative approach is that the comparative study in the measuring performance of NGO will have a relationship with human psychological, interactive and humanistic method and their performance. The qualitative approach helps researchers to understand and analyze the performances and identify factors contributing to the NGOs performance. The rationale behind chosing quantitative approach is that this study is an attempt to measure performance from numerical perspective.

\section{Population and sample size}

There are 31,284 NGOs working in the country having registration in Social Welfare Council as of Ashad 2071 and out of those only 88 NGOs work in the area of AIDS Abuse Control. Therefore population size of this research is 88 NGOs. Two NGOs one from Kathmandu valley and other from Makwanpur district have been selected as the sample unit respectively.

Types of data used for the analysis

- Primary data

- Secondary data

Primary data were collected from the structured questionnaire. Each questionnaire was coded immediately after collection for making convenient entry for computer use. The collected data was processed using SPSS version 19 software and Microsoft Office Excel to derive the value of different parameters. The values thus obtained have been analyzed, interpreted and finally concluded. The four point likert scale was as follows,
$1=$ disagree strongly
$2=$ disagree
$3=$ agree
4 = agree strongly 
Out of 50 questionnaires distributed at AMDA, we got back only 35 and out of 50 questionnaires distributed at GWP, we got back 45 questionnaires. A set of questions have been categorized into the different independent variables. 4 to 6 questions were asked in each independent variable. To analyze the factors contributing to the growth and causes of poor performance, separate group of questions were asked in the questionnaire.

\section{Data Analysis}

Data collected through questionnaires are coded and investigated for integrity, analyzed and presented in the useful outputs. SPSS statistical software is used for calculations.

\section{Regression analysis}

The linear regression model assumes that there is a linear or straight line relationship between the dependent variables like organizational performance and the independent variables like Quality Oriented, Work Climate, Employee's Satisfaction, Organizational Strategies, Organizational Diagnosis, Relationship, Personal Growth. In order to develop model for measuring the performance of NGO the regression analysis has been used. The multiple regression model has been formatted below:

In quantitative terms:

$$
\mathrm{Y}=\mathrm{f}\left(\mathrm{X}_{1}, \mathrm{X}_{2}, \mathrm{X}_{3}, \mathrm{X}_{4} \ldots \ldots\right)
$$

$Y=\beta_{0} X_{0}+\beta_{1} X_{1}+\beta_{2} X_{2}+\beta_{3} X_{3}+\beta_{4} X_{4}+\beta_{5} X_{5}+\beta_{6} X_{6}+\beta_{7} X_{7} \ldots \ldots \ldots \ldots+e t X_{4}$

Where,

$\mathrm{Y}=$ Organizational performance

$\mathrm{X}_{1}=$ Quality oriented

$\mathrm{X}_{3}=$ Employee's satisfaction

$\mathrm{X}_{5}=$ Organizational diagnosis

$\mathrm{X}_{7}=$ Personal growth $\beta_{0}=$ Slope constant

$\mathrm{X}_{2}=$ Work climate

$\mathrm{X}_{4}=$ Organizational strategies

$\mathrm{X}_{6}=$ Relationships

\section{Questionnaire Reliability}

Out of 281 responded 263 completed and returned the questionnaire. These questionnaires internal consistency was tested by using the Cronbach's alpha. For the total of the 40 items the Cronbach's alpha was found to be .894 .

Table 3.2: Reliability Statistics

\begin{tabular}{cc}
\hline Cronbach's Alpha & No. of Items \\
\hline .894 & 40 \\
\hline
\end{tabular}

\section{Data Presentation and Analysis}

Comparison of operation performance for AMDA and GWP 
Table 4.1: Descriptive Statistics for both NGO

\begin{tabular}{|l|ccc|ccc}
\hline \multicolumn{7}{c}{ Name of organization } \\
\hline variables items & \multicolumn{3}{c}{ AMDA } & \multicolumn{3}{c}{ GWP } \\
\hline Work Climate & Mean & $\begin{array}{c}\text { Std. } \\
\text { Deviation }\end{array}$ & Variance & Mean & $\begin{array}{c}\text { Std. } \\
\text { Deviation }\end{array}$ & Variance \\
Employee Satisfaction & $\mathbf{3 . 8 5 7}$ & $\mathbf{0 . 3 5 5}$ & $\mathbf{0 . 1 2 6}$ & $\mathbf{4 . 0 0 0}$ & $\mathbf{0 . 0 0 0}$ & $\mathbf{0 . 0 0 0}$ \\
Organizational Strategies & $\mathbf{3 . 7 4 3}$ & $\mathbf{0 . 4 4 3}$ & $\mathbf{0 . 1 9 7}$ & $\mathbf{3 . 9 7 8}$ & $\mathbf{0 . 1 4 9}$ & $\mathbf{0 . 0 2 2}$ \\
Organizational Diagnosis & 3.743 & 0.505 & 0.255 & 3.933 & 0.252 & 0.064 \\
Organizational Relationship & 3.543 & 0.657 & 0.432 & 3.489 & 0.506 & 0.256 \\
Personal Growth & 3.829 & 0.382 & 0.146 & 3.889 & 0.318 & 0.101 \\
Quality Oriented & $\mathbf{3 . 8 8 6}$ & $\mathbf{0 . 3 2 3}$ & $\mathbf{0 . 1 0 4}$ & $\mathbf{4 . 0 0 0}$ & $\mathbf{0 . 0 0 0}$ & $\mathbf{0 . 0 0 0}$ \\
\hline
\end{tabular}

In the comparative study of ADMA and GWP through the mean, standard deviation and variance, it can be found that work climate, personal growth, organizational strategies, organizational relationship and employee satisfaction at GWP were found higher as compared to the AMDA. This indicates that most of the variables items for the operational performance in the GWP are found with higher mean and low standard deviation along with low variance. Therefore, the overall operational performance of the GWP is higher as compared to AMDA.

\section{Correlation Analysis}

Table 4.2: Correlations

\begin{tabular}{|c|c|c|c|c|c|c|c|c|c|}
\hline & & OP & WC & $\mathbf{E S}$ & OS & OD & OR & PG & QO \\
\hline \multirow[t]{2}{*}{ OP } & Pearson Correlation & 1 & $.693 * *$ & $.422 * *$ & $.649 * *$ & $.542 * *$ & $.332 * *$ & $.735 * *$ & -0.06 \\
\hline & Sig. (2-tailed) & & 0 & 0 & 0 & 0 & 0.003 & 0 & 0.597 \\
\hline \multirow[t]{2}{*}{ WC } & Pearson Correlation & & 1 & $.642 * *$ & $.869 * *$ & $.629 * *$ & $.271 *$ & $.691 * *$ & -0.082 \\
\hline & Sig. (2-tailed) & & & 0 & 0 & 0 & 0.015 & 0 & 0.468 \\
\hline \multirow[t]{2}{*}{ ES } & Pearson Correlation & & & 1 & $.505^{* *}$ & $.345^{* *}$ & $.232 *$ & $.426^{* *}$ & 0.079 \\
\hline & Sig. (2-tailed) & & & & 0 & 0.002 & 0.038 & 0 & 0.488 \\
\hline \multirow[t]{2}{*}{ OS } & Pearson Correlation & & & & 1 & $.669 * *$ & $.268^{*}$ & $.751^{* *}$ & -0.046 \\
\hline & Sig. (2-tailed) & & & & & 0 & 0.016 & 0 & 0.683 \\
\hline \multirow[t]{2}{*}{ OD } & Pearson Correlation & & & & & 1 & $.330 * *$ & $.590 * *$ & 0.135 \\
\hline & Sig. (2-tailed) & & & & & & 0.003 & 0 & 0.234 \\
\hline \multirow[t]{2}{*}{ OR } & Pearson Correlation & & & & & & 1 & $.301 * *$ & -0.004 \\
\hline & Sig. (2-tailed) & & & & & & & 0.007 & 0.969 \\
\hline \multirow[t]{2}{*}{ PG } & Pearson Correlation & & & & & & & 1 & 0.05 \\
\hline & Sig. (2-tailed) & & & & & & & & 0.658 \\
\hline \multirow[t]{2}{*}{ QO } & Pearson Correlation & & & & & & & & 1 \\
\hline & Sig. (2-tailed) & & & & & & & & \\
\hline
\end{tabular}


Where, $O P=$ Operational performance, $W C=$ Working Condition, ES $=$ Employee's Satisfaction, OS

= Organizational Strategies, $O D=$ Organizational Diagnosis, OR = Organizational Relationship, $P G$ $=$ Personal Growth and $Q O=$ Quality Oriented

From the correlation analysis in the table 5.33, it is obvious that the correlation between operational performance and the personal growth is found highest i.e. $.735^{* *}$ as well as the sig. value is also highly significant at the 0.01 level. Thus, the alternative hypothesis "H2: there is a significance association between the operational performance and the personal growth" is proved.

'H1: There is a significance relationship between the operational performance and work climate'.

H3: Employee satisfaction has the significance relationship with the operational performance of an organization.

Operational performance is also correlated with employee's satisfaction, organizational diagnoses, relationship and personal growth. The relationship of operational performance with the quality oriented was not found significant which indicates negative correlation between them.

\section{Regression analysis}

Table 4.3: Model Summary

\begin{tabular}{ccc}
\hline Model & $\mathbf{R}$ & R Square \\
1 & $.675 \mathrm{a}$ & 0.455 \\
\hline
\end{tabular}

a. Predictors: (Constant), Quality oriented, Work Climate, Organizational Diagnosis, Personal Growth, Organizational Relationship, Employee Satisfaction, Organizational Strategies

b. Dependent Variable: Operational performance

Since the value of $\mathrm{R}$ ranges from 0 to 1 . Larger value of $\mathrm{R}$ indicates stronger relationship between dependent and predictor variables which is $\mathrm{R}(0.455)$ in this model. The adjusted $\mathrm{R}$ square value reflects the goodness of fit of the model in the population. The linear regression summary model also indicates that this model can explain about 45.5 percent of the proportion of variance of operational performance by the variables i.e. Quality oriented, Work Climate, Organizational Diagnosis, Personal Growth, Organizational Relationship, Employee Satisfaction, organizational Strategies. 


\section{Coefficients}

Table 4.4: Coefficients

\begin{tabular}{|c|c|c|c|c|c|c|}
\hline & \multirow[t]{2}{*}{ Model } & \multicolumn{2}{|c|}{$\begin{array}{c}\text { Unstandardized } \\
\text { Coefficients }\end{array}$} & \multirow{2}{*}{$\begin{array}{c}\text { Standardized } \\
\text { Coefficients }\end{array}$} & \multirow[t]{2}{*}{$\mathbf{T}$} & \multirow[t]{2}{*}{ Sig. } \\
\hline & & B & Std. Error & & & \\
\hline \multirow[t]{8}{*}{1} & (Constant) & 1.216 & .796 & & 1.529 & .131 \\
\hline & Work Climate & 1.377 & .266 & .202 & 1.417 & .001 \\
\hline & Employee Satisfaction & .519 & .195 & .379 & 2.661 & .010 \\
\hline & Organizational Strategies & .235 & .169 & .202 & 1.391 & .039 \\
\hline & Organizational Diagnosis & .085 & .087 & .108 & .982 & .049 \\
\hline & Organizational Relationship & .425 & .163 & .324 & 2.604 & .011 \\
\hline & Personal Growth & 1.175 & .268 & .084 & .652 & .017 \\
\hline & Quality oriented & -.020 & .018 & -.102 & -1.123 & .265 \\
\hline
\end{tabular}

a. Dependent Variable: Operational performance

According to the table 4.14 the constant value is 1.216. The values $1.377, .519, .235, .085, .425,1.175$ and -.020 which are the partial regression coefficient of the work climate, employee satisfaction, organizational strategies, organizational diagnosis, organizational relationship, personal growth and quality oriented respectively. The model thus conclude that, 1 unit change in product quality, service delivery and price will change $1.377, .519, .235, .085, .425,1.175$ and -.020 change in unit in operational performance respectively. Work Climate and personal growth are most influential variables items and highly influences the operational performance. On the other hand the partial regression coefficient of quality oriented is found to be negative and is insignificant i.e. $\mathrm{p}<0.05$. Therefore quality oriented seems to be less influential factor which hardly affect the operational performance in this research. Following model is applied to calculate the organizational performance.

Operational performance $(\mathrm{OP})=\alpha+\beta^{0} \mathrm{WC}+\beta_{1} \mathrm{ES}+\beta_{2} \mathrm{PS}+\beta_{3} \mathrm{OD}+\beta_{4} \mathrm{R}+\beta_{5} \mathrm{PG}+\beta_{6} \mathrm{QO}$ Or

Operational Performance $(\mathrm{OP})=1.216+1.377 \mathrm{WC}+.519 \mathrm{ES}+.235 \mathrm{PS}+.085 \mathrm{OD}$ $+.425 \mathrm{OR}+1.175 \mathrm{PG}+-.020 \mathrm{QO}$

$\mathrm{OP}=$ Operational performance

$\mathrm{ES}=$ Employee's Satisfaction

OD $=$ Organizational Diagnosis

$\mathrm{PG}=$ Personal Growth
$\mathrm{WC}=$ Working condition

PS = Organizational strategies

$\mathrm{R} \quad=$ Relationship

$\mathrm{QO}=$ Quality Oriented 
Table 4.5: Higher preferences given by organization

\begin{tabular}{|l|c|c|}
\hline \multicolumn{1}{|c|}{ Activities } & Ranking & \\
\hline Goals and work plans & 1st & 191 \\
\hline Communication & 2nd & 230 \\
\hline Quality enhancement & 3rd & 300 \\
\hline Rewarding performance & 4th & 352 \\
\hline Integrity and uniqueness of the individual or group & 5th & 373 \\
\hline Conflict management & 6th & 381 \\
\hline Learning through feedback & 7th & 416 \\
\hline
\end{tabular}

When asked with the respondent about the preferences given by organization, Goals and work plans were amongst the top priority of the respondents, which was then followed by communication. The employees in the organization also opined that quality enhancement and rewarding performance were also placed in the 3rd and 4th position. The integrity and uniqueness of the individual or group, conflict management and learning through feedback were placed at 5 th, 6 th and 7 th position respectively.

\section{Summary}

\section{Impression from study}

- Personal growth can be the main factor, which can contribute in the operational performance of organization. From the correlation analysis, it is obvious that the correlation between operational performance and the personal growth is found highest.

- Working conditions and organizational strategies also highly correlate with the operational performance. Amongst all the independent variables, the work climate and personal growth are most influential variables items and highly influence the operational performance.

- Performance of the GWP is higher as compared to AMDA. The variable items taken for operational performance in AMDA, personal growth has the highest impact on the performance while personal growth variable has the least effect on the performance. Whereas in case of GWP organization diagnosis has the highest impact and work climate and personal growth has least impact on the performance in GWP.

- Among the variable items considered at the employee's level, degree of job satisfaction and personal growth and working conditions are found to influence the operational performance. It was found that low in these stated variables, would affect more in performance. Among the six variables considered at the organizational level, quality orientation and personal relationship, organizational diagnosis makes the differences in performance. Organizational conditions or environment was also found to influence the operational performance. 
- There is a significance association between the operational performance and the personal growth. There is a significance relationship between the operational performance and work climate. Likewise, employee satisfaction has the significance relationship with the operational performance of an organization. These statements have been proved through the hypothesis where the sig value of all these three statement has been found highly significant (i.e. $\mathrm{p}<0.5$ ).

- From the descriptive tables of the operational performance variables, variables with higher mean score and lower standard deviation (work climate and personal growth) contribute more to the performance.

- According to the comparative study of descriptive statistic, for both NGO, it was found that that most of the variables items for the operational performance in the GWP are found higher. The overall operational performance of the GWP is higher as compared to AMDA.

- Another significant contribution from the study, is the effect of the variations at the employee's satisfaction level, the organizational level and the conditions or the environment prevailing in the organization, which is also termed as working condition.

\section{Recommendation for further research}

- The NGO and INGO in Nepal must realize that apart from employee satisfaction and personal growth, quality orientation, personal relationship, organizational diagnosis, strategies and working condition, they should also carefully monitor the other factors like leadership, resources, people and society and others.

- The organizational performance can be measured for each department like the Production, Administrative, Management, Technology etc.

- Monitoring and evaluating of the job performance can be measured annually or twice yearly. These will help provide employers identify what they are doing well what areas need improvement.

- Through the research, it can be suggested that the organization should support employee's personal growth and development by providing education and learning opportunities, cross training, coaching, and other interactions.

- Employee's satisfactions were also amongst one of the factor, which contributes in the overall performance of an organization. Therefore, it is suggested that the organization should increase their human resource in the short-term obligation. 


\section{References}

Bissell, B. (2008). 'Organizational Assessment \& Diagnosis', International Journal of Organizational Analysis, vol. 16, pp.7-17.

Bowen, D.E. \& Ostroff, C. (2004). 'Understanding HRM-frim Performance Linkages, the Role of the 'Strength' of the HRM System', Academy of Management review, 29(2): pp. 203-221.

Campbell, D. J. \& Furrer, D. M. (1995). 'Goal Setting and Competition as Determinants of Task Performance', Journal of Organizational Behavior, Vol. 16, pp. 377-389.

Dhakal, T.N (2006). NGOS in Livelihood Improvement, Nepalese Experience, Adroit publishers, New Delhi.

Dhakal, T. N. (2007). 'Challenges of Civil Society Governance in Nepal', JOAAG, Vol. 2. No. 1, pp. 23-26.

Harter, J. K. and et al. (2002). 'Business-unit level relationship between employee satisfaction, employee engagement, and business outcomes: A meta-analysis', Journal of Applied Psychology, pp. 87, 268279.

Islam, M. Z., \& Siengthai, S. (2009). 'Quality of work life and organisational performance: empirical evidence from Dhaka Export Processing Zone', Paper presented at the ILO Conference on 'Regulating for Decent Work', held at the International Labour Office, Geneva, July 8-10.

Lu, H. and et al. (2005). 'Job Satisfaction among Nurses: A Literature Review' . International Journal of Nursing Studies, 42(2).

Morrison, a., Teixera, R. (2004). 'Small Business Performance: A Tourism Sector Focus'. Journal of Small Business and Enterprise Development, Vol. 11, pp. 166-173.

Price, J. I. (2001). 'Reflections on the determinants of voluntary turnover', International Journal of Manpower, 22(7), pp 660.

Roberts, H. E, Foti, R. J. (2002).'Evaluating the Interaction between Self-leadership and Work Structure in Predicting Job Satisfaction', Journal of business and psychology, 12, pp.257-67.

Rummler, G. A. \& Brache, A. P. (1990). Improving Performance: How to Manage the White Space on the Organization Chart, Jossey-Bass Publishers, San Franscisco.

Sempane, M. E. and et al. (2002). 'Job satisfaction in relation to organisational culture', Journal of Industrial Psychology, 28(2), 23-30. 